\title{
INDONESIAN CHILDREN'S QUALITY OF LIFE: A CASE STUDY OF RESIDENTS RELOCATION TO FLATS IN JAKARTA PROVINCE
}

\author{
Rahmah Hida Nurrizka*1 and Rafiah Maharani ${ }^{1}$ \\ Public Health Department, Universitas Pembangunan Nasional (UPN) Veteran Jakarta-Indonesia \\ Corresponding author: Rahmah Hida Nurrizka \\ Email: rh.nurrizka@upnvj.ac.id
}

\begin{abstract}
Resident relocation to flats policy becomes a strategy of the Jakarta Provincial Government to overcome illegal settlements and slum areas. The relocation is also aimed to improve the quality of life, particularly of the children. This research analyses the determinant factors of the quality of life of children who are moved to the flats due to the relocation. This research uses the Kid-KINDLR questionnaire to collect data of children in the range of age 7-13 years and the Z-score method to process the data and to build an analysis. The Z-score > 0 indicates a good quality of life, while Z-score $<0$ is otherwise. The result shows that $48 \%$ of the children have a good quality of life and $52 \%$ of the children have a poor quality of life (mean $=91.45$ and $S D=9.559$ ). There is a positive correlation between the quality of life of children and the pattern of nutrients intake of children $(r=0.053, p=0.518)$, the education of the head of the family $(r=0.058, p=0.478)$, and the household income $(r=0.070, p=0.401)$. Whereas, the negative correlation between the quality of life of children and the number of family members $(r=-0.088, p=0.284)$. This research argues that to increase the quality of life of children, the facilities in the flats must be built properly for the growth of the children. In addition, family involvement must be improved to provide a high quality of nutrients intake for the children.
\end{abstract}

Keywords: children's quality of life, determinant factors, flats, Indonesia

\section{INTRODUCTION}

The population of Jakarta has grown over its supporting capacity ${ }^{1,2}$. The population growth rate reached $1,05 \%$ per year ${ }^{3}$ and made Jakarta a city with the highest population density in the South East Asia ${ }^{4}$. In 2017, the population density was 15.663 people per square kilometers ${ }^{5}$.

One of the factors that promote the high population growth in Jakarta is urbanization. The net migration rate in Jakarta reached 946.183 people in $2015^{6}$. The migration was driven by economic and social appeal ${ }^{7}$. The economic factor is the main reason why people migrate to Jakarta due to its status as the center of economy in Indonesia ${ }^{8}$.

Given the limited land in Jakarta, the competition for land uses such as for housing is critically high?. The growth of residential properties is not comparable to the demand, causing expensive property prices in Jakarta ${ }^{10}$. Consequently, the citizens especially the poor are hard to afford a proper place to live ${ }^{11}$.

Consequently, these poor people grab lands that are forbidden to be built as residential areas, such as riverbanks, land under bridges, and land along train railways ${ }^{12}$. As these areas are not well regulated, the illegal and slum residential areas are growing at any corner of Jakarta ${ }^{13,14}$. These areas are prone to flooding ${ }^{15}$, social conflicts, and high health risks ${ }^{16}$.
To overcome this issue, Jakarta Provincial Government initiated a controlling measure through resident relocation scheme. The scheme relocates the residents from illegal areas to flats $^{17}$. Given the lack of land in Jakarta, a vertical building is considered the best solution ${ }^{18}$.

Living in a flat which offers a better environment and facilities are expected to improve the life quality of the residents, particularly the children ${ }^{19}$. However, these changes are not easy to carry out for the children.

Psychologically, children need some times to adapt to the changes in physical and social surroundings ${ }^{20}$. Moreover, the physical surrounding changes are quite significant in terms of residential models, from horizontal to a vertical residence. When the adaptation fails to run smoothly, it will affect the children's growth and intellectuality ${ }^{21}$.

Improving the quality of life of children in the relocation scheme must be the main concern of the government. The flats must be childrenfriendly. For instances, they have playgrounds and health and counseling facilities and are close to the education center. However, those concerns are frequently neglected during the development of the flats.

This research tries to find the determinant factors of the quality of life of the children who are relocated to the flats. The aims of this research are to analyze the quality of life of the children 
and the correlation between the quality of life of children and the determinant factors such as the pattern of nutrients intake of children, the education of the head of a family, the household income, and the number of family members.

\section{METHODS}

\section{Study Location}

There are three flats in Jakarta that become the relocation places: (1) Flat Marunda, Cilincing, North Jakarta, (2) Flat Rawa Bebek, Cakung, East Jakarta, and (3) Flat Jatinegara Barat, Jatinegara, East Jakarta.

\section{Samples of Study}

The samples of this research are the children in the range of age 7-13 years who live in the flats and are the children of the family relocated by the Jakarta Provincial Government. The samples consist of 150 samples which are developed based on family. There are two steps in determining the sample. First, identifying flats for study location. Second, identifying the household and the child. This research sets the sample as much as 30\% of the total population. The sampling technique is systematically random sampling.

\section{Indicators for Quality of Life of Children}

The measurement of the quality of life of the children in this research uses the Kid-KINDL ${ }^{R}$ questionnaire. It is relevant to be used to measure the children's quality of life due to its flexibility to reach any children's condition. The Kid-KINDL ${ }^{\mathrm{R}}$ questionnaire is frequently adopted in many research's related to the quality of life of children 22,23 .

The Kid-KINDL ${ }^{\mathrm{R}}$ questionnaire used in this research is the Kid-KINDL ${ }^{R}$ of children aged 7-13 years. There are six dimensions were measured: (1) physical well-being, (2) emotional well-being, (3) self-esteem, (4) family relationship, (5) friend's relationship, and (6) everyday functioning in school ${ }^{24}$.

\section{Method of Measurement and Analysis}

The measurement of the quality of life of children in this research uses the Z-score method. The Zscore is used to find more details of the extent of the position of an object from the average value measured from the standard deviation. Moreover, the Z-score can also find the position of a score in a distribution. The position in distribution is shown with the symbol $+/$ - that shows that it is positive $(Z$-score $>0)$ if it is above the average and negative $(Z$-score $<0)$ if it is below the average ${ }^{25}$. In this research, the Z-score $>0$ shows a good quality of life while Z-score $<0$ shows a poor quality of life. Further, the measurement result is connected to the determinant factors of the quality of life of the children that consist of the pattern of nutrients intake of children, the education of the head of the family, the household income, and the number of the family members.

\section{Ethical Considerations}

This research was granted permission by the Jakarta Provincial Government and Universitas Pembangunan Nasional (UPN) Veteran JakartaIndonesia. All respondents have explained the objectives of the study and secured written informed consent from participants prior to data collection. Ethics clearance was obtained from Ethics Committee Universitas Pembangunan Nasional (UPN) Veteran Jakarta-Indonesia with the study protocol code of No: B/1582/VIII/2018/KEPK.

\section{RESULTS}

Table 1 reveals the socio-demographic characteristics of the respondents. The result of the univariate analysis shows that the proportion respondents by location are: $38.7 \%$ of them live in Merunda Flats, $36.0 \%$ of them live in Jatinegara Barat Flats, and 25.3\% of them live in Rawa Bebek Flats. The proportion of respondents based on indigenous people category (Betawi) is 37.3\%, while non-indigenous people are $62.7 \%$. Based on sex, $41.3 \%$ are male and $58.7 \%$ are female. Most (71.3\%) of the respondents aged $7-10$ years and $28.7 \%$ of them aged $11-13$ years. Based on a number of family members, the majority (61.3\%) is 5 and above, while a number of family members of $1-4$ people are $38.7 \%$.

Regarding the education of the head of the family, the majority $(79.3 \%)$ of respondents are junior and senior high school, while $16.7 \%$ of them are primary school and $4.0 \%$ is a university. Regarding the education of mother, the majority (75.3\%) of respondents are junior and senior high school, while $21.3 \%$ of them are primary school and 3.3\% is a university. Most (74.0\%) of respondents aged $25-45$ years and $26.0 \%$ aged 46 years and above. Based on the work of the head of the family, $86.7 \%$ are working and $13.3 \%$ are unemployed.

Regarding income of the head of the family per month, $30.0 \%$ of respondents have income USD 245.0 and above, $24.0 \%$ of them have income USD 126.0-209.9, 23.3\% of them have income USD 210.0-244.9 and $22.7 \%$ of them have income USD 0.0-125.9. 
Table 1: Socio-demographic characteristics of the respondents $(n=150)$

\begin{tabular}{|c|c|c|}
\hline Characteristics & $\mathbf{N}$ & $\%$ \\
\hline \multicolumn{3}{|l|}{ Location } \\
\hline Merunda flats & 58 & 38.7 \\
\hline Jatinegara Barat flats & 54 & 36.0 \\
\hline Rawa Bebek flats & 38 & 25.3 \\
\hline \multicolumn{3}{|l|}{ Indigenous peoples } \\
\hline Yes & 56 & 37.3 \\
\hline No & 94 & 62.7 \\
\hline \multicolumn{3}{|l|}{ Sex } \\
\hline Male & 62 & 41.3 \\
\hline Female & 88 & 58.7 \\
\hline \multicolumn{3}{|l|}{ Age of the child (years) } \\
\hline $7-10$ & 107 & 71.3 \\
\hline $11-13$ & 43 & 28.7 \\
\hline \multicolumn{3}{|l|}{ Number of family members } \\
\hline $1-4$ & 58 & 38.7 \\
\hline 5 and above & 92 & 61.3 \\
\hline \multicolumn{3}{|l|}{ Education of the head of family } \\
\hline Primary school & 25 & 16.7 \\
\hline Junior and senior high school & 119 & 79.3 \\
\hline University & 6 & 4.0 \\
\hline \multicolumn{3}{|l|}{ Education of mother } \\
\hline Primary school & 32 & 21.3 \\
\hline Junior and senior high school & 113 & 75.3 \\
\hline University & 5 & 3.3 \\
\hline \multicolumn{3}{|l|}{ Age of the head of family (years) } \\
\hline $25-45$ & 111 & 74.0 \\
\hline 46 and above & 39 & 26.0 \\
\hline \multicolumn{3}{|l|}{ Work of the head of family } \\
\hline Work & 130 & 86.7 \\
\hline Unemployment & 20 & 13.3 \\
\hline \multicolumn{3}{|c|}{ Income of the head of family per month } \\
\hline USD $0-125.9$ & 34 & 22.7 \\
\hline USD 126.0-209.9 & 36 & 24.0 \\
\hline USD 210.0-244.9 & 35 & 23.3 \\
\hline USD 245.0 and above & 45 & 30.0 \\
\hline
\end{tabular}

The measurement results of the children's quality of life in three flat locations varied. Children who live in Merunda Flat have a better quality of life compared to children who live in other flats. This can be seen from the proportion of children who have Z-score $>0$ are higher compared to the Zscore $<0$. The proportion of the children with Zscore $>0$ is $56.9 \%$ while Z-score $<0$ are $43.1 \%$ $($ mean $=92.58$ and SD $=10.17)$. This means that $56.9 \%$ of children have a better quality of life.

In other two flats, the Jatinegara Barat and Rawa Bebek flats, the proportion of the children who have Z-score $>0$ is lower than those with the Zscore $<0$. In Jatinegara Barat Flat, the proportion of children with Z-score $>0$ is $38.9 \%$ while Z-score $<0$ is $61.1 \%$ (mean $=89.90$ and $S D=8.24)$. In Rawa Bebek Flat, the proportion of children with Zscore $>0$ is $47.4 \%$ while Z-score proportion of those with Z-score $<0$ is $52.6 \%$ (mean $=91.92$ and SD $=10.26)$.

In total, the proportion of the children with Zscore $>0$ is $48 \%$ while Z-score proportion of those with Z-score $<0$ is $52 \%$ (mean 91.45 and SD = 9.55). There are still many proportions of the children with poor quality of life compared to those who have a good quality of life in these flats.

When looking at the assessment results based on the dimensions of the quality of life, the physical well-being of all children in the three flats is better compared to the other five dimensions. The proportion of children who have Z-score $>0$ in the physical well-being dimension is $60.7 \%$ (mean $=15.95$ and SD = 2.57). Another prominent dimension is everyday functioning in school, the proportion of children who have Z-score $>0$ is $56.0 \%$ (mean $=14.87$ and SD = 2.71). However, this dimension was found to be lower in Rawa Bebek Flat with the proportion of children who have Zscore of $47.4 \%$ (mean $=14.07$ and SD = 3.02). Meanwhile, the dimensions of the family relationships are the worst, the proportion of children who have Z-score $<0$ is $51.3 \%$ (mean = 15.31 and $S D=2.36$ ). The results of the detailed assessment can be seen in Table 2 . 
Table 2: The assessment results of the quality of life of children based on the flats dimension and location $(n=150)$

\begin{tabular}{|c|c|c|c|c|c|c|c|}
\hline \multirow[t]{2}{*}{ Location } & \multicolumn{6}{|c|}{ Dimensions } & \multirow{2}{*}{$\begin{array}{l}\text { Quality } \\
\text { of Life } \\
\text { (QoL) }\end{array}$} \\
\hline & $\begin{array}{l}\text { Physical } \\
\text { well- } \\
\text { being }\end{array}$ & $\begin{array}{l}\text { Emotional } \\
\text { well-being }\end{array}$ & $\begin{array}{c}\text { Self- } \\
\text { esteem }\end{array}$ & Family & Friends & $\begin{array}{l}\text { Everyday } \\
\text { functioning } \\
\text { in school }\end{array}$ & \\
\hline $\begin{array}{l}\text { Merunda Flats } \\
\text { - } \mathrm{N} \\
\text { - Mean } \\
\text { - SD } \\
\text { - Z-score > } 0 \\
\text { - Z-score < } 0 \\
\text { Jatinegara Barat } \\
\text { Flats }\end{array}$ & $\begin{array}{r}58 \\
15.34 \\
2.49 \\
53.4 \% \\
46.6 \%\end{array}$ & $\begin{array}{r}58 \\
16.12 \\
2.75 \\
62.1 \% \\
37.9 \%\end{array}$ & $\begin{array}{r}58 \\
15.81 \\
2.90 \\
58.6 \% \\
41.4 \%\end{array}$ & $\begin{array}{r}58 \\
15.24 \\
2.38 \\
48.3 \% \\
51.7 \%\end{array}$ & $\begin{array}{r}58 \\
14.93 \\
2.05 \\
62.1 \% \\
37.9 \%\end{array}$ & $\begin{array}{r}58 \\
15.13 \\
2.67 \\
56.9 \% \\
43.1 \%\end{array}$ & $\begin{array}{r}58 \\
92,58 \\
10.17 \\
56.9 \% \\
43.1 \%\end{array}$ \\
\hline $\begin{array}{l}\text { - } \mathbf{N} \\
\text { - } \text { Mean } \\
\text { - } \text { SD } \\
\text { - Z-score > } 0 \\
\text { - Z-score < } 0 \\
\text { Rawa Bebek Flats }\end{array}$ & $\begin{array}{r}54 \\
15.09 \\
2.31 \\
40.7 \% \\
59.3 \%\end{array}$ & $\begin{array}{r}54 \\
15.42 \\
2.24 \\
57.4 \% \\
42.6 \%\end{array}$ & $\begin{array}{r}54 \\
14.77 \\
2.89 \\
46.3 \% \\
53.7 \%\end{array}$ & $\begin{array}{r}54 \\
15.50 \\
2.32 \\
51.9 \% \\
48.1 \%\end{array}$ & $\begin{array}{r}54 \\
13.96 \\
2.34 \\
33.3 \% \\
66.7 \%\end{array}$ & $\begin{array}{r}54 \\
15.14 \\
2.46 \\
61.1 \% \\
38.9 \%\end{array}$ & $\begin{array}{r}54 \\
89.90 \\
8.24 \\
38.9 \% \\
61.1 \%\end{array}$ \\
\hline $\begin{array}{l}-\mathrm{N} \\
\text { - } \text { Mean } \\
\text { - } \mathrm{SD} \\
\text { - Z-score > } 0 \\
\text { - Z-score < } 0 \\
\text { Total }\end{array}$ & $\begin{array}{r}38 \\
16.07 \\
2.67 \\
65.8 \% \\
34.2 \%\end{array}$ & $\begin{array}{r}38 \\
16.31 \\
2.69 \\
63.2 \% \\
36.8 \%\end{array}$ & $\begin{array}{r}38 \\
15.47 \\
2.77 \\
50.0 \% \\
50.0 \%\end{array}$ & $\begin{array}{r}38 \\
15.15 \\
2.42 \\
44.7 \% \\
55.3 \%\end{array}$ & $\begin{array}{r}38 \\
14.81 \\
2.69 \\
60.5 \% \\
15.3 \%\end{array}$ & $\begin{array}{r}38 \\
14.07 \\
3.02 \\
47.4 \% \\
52.6 \%\end{array}$ & $\begin{array}{r}38 \\
91.92 \\
10.26 \\
47.4 \% \\
52.6 \%\end{array}$ \\
\hline $\begin{array}{l}\text { - } \mathrm{N} \\
\text { - Mean } \\
\text { - SD } \\
\text { - Z-score > } 0 \\
\text { - Z-score < } 0\end{array}$ & $\begin{array}{r}150 \\
15.44 \\
2.49 \\
52.0 \% \\
48.0 \%\end{array}$ & $\begin{array}{r}150 \\
15.95 \\
2.57 \\
60.7 \% \\
39.3 \%\end{array}$ & $\begin{array}{r}150 \\
15.35 \\
2.88 \\
52.0 \% \\
48.0 \%\end{array}$ & $\begin{array}{r}150 \\
15.31 \\
2.36 \\
48.7 \% \\
51.3 \%\end{array}$ & $\begin{array}{r}150 \\
14.55 \\
2.36 \\
51.3 \% \\
48.7 \%\end{array}$ & $\begin{array}{r}150 \\
14.87 \\
2.71 \\
56.0 \% \\
44.0 \%\end{array}$ & $\begin{array}{r}150 \\
91.45 \\
9.55 \\
48.0 \% \\
52.0 \%\end{array}$ \\
\hline
\end{tabular}

The relationship of determinant factors to the quality of life of children shows a positive correlation on three factors, namely household income, education of the head of the family, and the pattern of nutrient intake of the children. The greater the household income, the better the quality of life of the children $(r=0.070, p=$ 0.401 ). Likewise, the education of the head of the family, children with a well-educated head of the family have a good quality of life compared to children with a low-educated head of the family $(r=0.058, p=0.478)$. Furthermore, children who demonstrate a good pattern of nutrient intake are proven to have a good quality of life $(r=0.053, p$ $=0.518$ ).

On the other hand, the factor of the number of family members shows a negative correlation. The number of family members is the worse the quality of life of the children $(r=-0.088, p=$ $0.284)$. It can be seen more clearly in figure 1 .

\section{DISCUSSION}

The resident relocation from the illegal housing and slum areas to the flats have not yet given any impacts towards the improvement of the quality of life of children. The results of the research show that $52 \%$ of the children assessed have a poor quality of life. This occurred because the construction of the flats is not properly designed for the children.

The concept of vertical building with a small number of playgrounds is one of the reasons why children lose the opportunity to play and interact socially. Whereas, the good environment and social interaction are some of the factors that support the growth of the children and strengthen the intelligence and emotional skills of the children26,27.

Besides, the area of occupancy in the flat is very small, which is $5 \times 6$ meters per unit with the average family members of 5-6 people, the ratio of per capita occupancy is far from proper. When a family lives in a cramped house, the social interaction among family members become worse28 and it affects the quality of life29,30. 

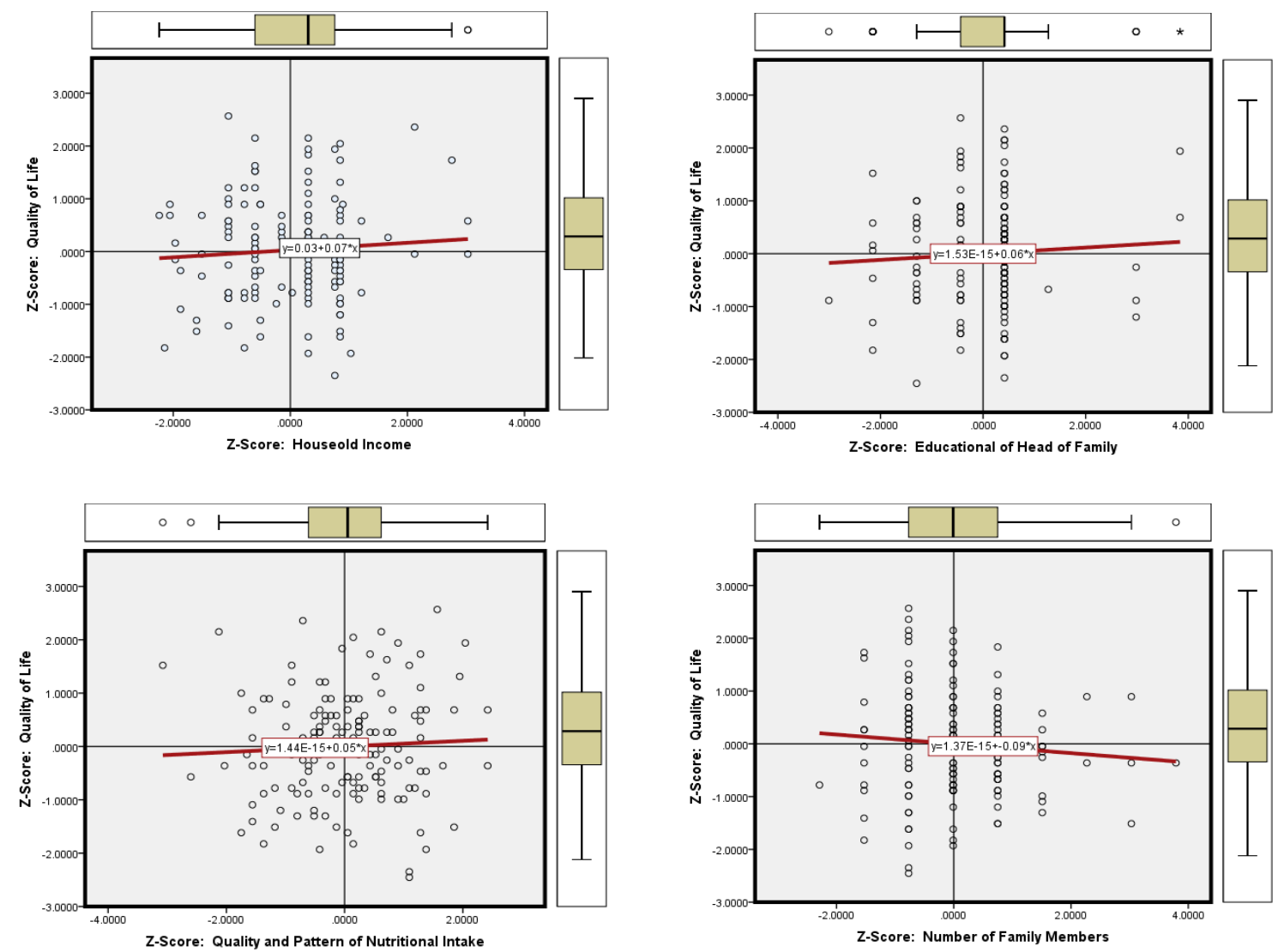

Figure 1: Correlation between the Quality of Life of Children and the Determinant Factors $(n=150)$

The relocation policy is a strategic breakthrough in spatial planning in Jakarta. However, the government should not only be focused on improving spatial planning but also designing the concept of flats that is suitable for children. This has not been a priority in flats development.

This happens because the construction of the flats is not designed to support children development. Therefore, flats managers must add facilities in the form of playgrounds and proper social interaction spaces for children's activities. Other supporting facilities such as library and counseling facilities as well as health facilities need to be added to support the children's knowledge and mentality.

Beside the factor of occupancy eligibility, the quality of life of children is also influenced by the socio-economic conditions of the family and the pattern of nutrient intake. Children from a family with high-income have a good quality of life. This happens because the high-income family has the ability to provide better basic needs for children ${ }^{31}$. So that children feel comfortable with these conditions.

The education of the head of the family also determines the quality of life of the children. Well-educated heads of the family have children with good quality of life. This is because the educational background makes the heads of the family have more empathy towards the needs of their children. The social interaction in the family is also better because the heads of the family can protect the children well ${ }^{32}$.

Lastly, this research found that children with good quality and pattern of nutrient intake have a good quality of life. This is because the quality and pattern of the nutrient intake determine the children's health ${ }^{33}$. Children with good quality and pattern of nutrient intake have a low risk of getting sick ${ }^{34}$. Hence, their growth is good. Children with good growth have a good quality of life. Therefore, the children who live in flats must get good quality and patterns of nutrient intake. They must get a nutrition improvement program which is included in "Program Keluarga Harapan" $(\mathrm{PKH})$. This program is one of the government programs to improve the welfare of the poor in Indonesia.

\section{CONCLUSIONS}

From this research, it can be concluded that the relocation of residents by the Jakarta Provincial Government from illegal housing and slum areas to flats has not been able to improve the quality of life of children. Flats do not provide good space for child development. Furthermore, the socioeconomic factors and family nutrition intake greatly influence the quality of life of children. One thing that needs attention is the quality and nutrient intake of the children. This factor determines not only the quality of life of children but also plays an important role to support the health, growth, and intelligence of children. 


\section{ACKNOWLEDGMENTS}

We are grateful to the Jakarta Provincial Government and the head of flats management, whom both gave a priceless contribution in supporting this study, particularly during the data collection. We also would like to thank the Research and Community Service Institution of Universitas Pembangunan Nasional (UPN) Veteran Jakarta-Indonesia and Ministry of Research, Technology and Higher Education of the Republic Indonesia for their institutional support throughout this study.

\section{REFERENCES}

1. Putri FR, Wibirama S, et al. Population Condition Analysis of Jakarta Land Deformation Area. IOP Conference Series: Earth and Environmental Science 148(2018)012007. doi: 10.1088/1755$1315 / 1 / 012007$.

2. Rustiadi E, Pribadi DO, Pravitasari AE, et al. The Dynamics Population, Economic Hegemony and Land Use/Cover Change of Jabodetabek Region (Jakarta Megacity). ATLAS: Land Use/Cover Change in Selected Regions in The World Vol. IGU-LUCC Research Report 2012. pp. 51-56.

3. Central Bureau of Statistic Republic of Indonesia, National Development Planning Agency Republic of Indonesia and United Nation Population Fund. Indonesia Population Projection, 2010-2013. (cited 2018 October 21). Available from: https: / / www.bappenas.go.id/files/5413/9 148/4109/Proyeksi_Penduduk_Indonesia_2 010-2035.pdf

4. Gaughan AE, Steven FR, Linard C, Jia P, Tatem AJ. High Resolution Population Distribution Maps for Southeast Asia in 2010 and 2015. PLoS ONE 2013 8(2): e55882. doi: $10.1371 /$ journal.pone. 0055882

5. Central Bureau of Statistic Province of DKI Jakarta. Province of DKI Jakarta in Figures 2017. (cited 2018 October 21). Available from:

https://jakarta.bps.go.id/publication/201 7/08/16/3e3564fb6453d384983128b0/prov insi-dki-jakarta-dalam-angka-2017.html

6. Central Bureau of Statistic Republic of Indonesia. Jakarta Migration Statistics: Intercensal Population Survey, 2015. (cited 2018 October 21). Available from: https://www.bps.go.id/publication/2016/ 01/05/184f64dc56630b52f5508695/statisti k-migrasi-dki-jakarta-hasil-surveipenduduk-antar-sensus-2015.html

7. Pravitasari AE. Study on Impact of Urbanization and Rapid Urban Expansion in
Java and JABODETABEK Megacity, Indonesia. Dissertation in Kyoto University. doi: 10.14989/doctor.k19347.

8. Firman T. The Urbanisation of Java, 20002010: Toward the Island of Mega-Urban Region. Asian Population Studies Volume 13, 2017-Issue $1 . \quad$ doi: 10.1080/17441730.2016.1247587.

9. Elmanisa AM, et al. Land Price Mapping of Jabodetabek, Indonesia. Geoplanning: Journal of Geomatics and Planning, 4(1), 53-62, 20117. doi:10.14710/geoplanning.4.1.53-62

10. Endri. Analysis of The Impact of Macroeconomic Shock on Residential Property Price Index In Jabodebek-Banten. Saudi Journal of Business and Management Studies, Vol-3, Iss-5 (May, 2018): 523-539. doi: $10.21276 /$ sjbms.2018.3.5.4.

11. Sustikarini A, Kabinawa LNRW. Urban and Global Populism: An Analysis of Jakarta as Resilient City. IOP Conference Series: Earth and Environmental Science 126 (2018) 012059 . doi: 10.1088/17551315/126/1/012059.

12. Padawangi R, Douglass M. Water, Water Everywhere: Toward Participatory Solution to Chronic Urban Flooding in Jakarta. Pacific Affairs, Volume 88, No. 3 September 2015. doi: $10.5509 / 2015883517$.

13. Alzamil SW. Evaluating Urban Status on Informal Settlements in Indonesia: A Comparative Analysis of Three Case Study in North Jakarta. Journal of Sustainable Development, Vol. 11, No. 4; 2018. doi: 10.5539/jsd.v11n4p148.

14. Nurdiansyah A. Urban Slum Upgrading Policy in Jakarta (Case Study: Kampung Deret Program Implementation). The Indonesia Journal of Planning and Development, 3(1). 2018. doi: 10.14710/ijpd.3.1.19-31.

15. Garschagen $M$, Surtiari KAG, Harb $M$. Is Jakarta's New Flood Risk Reduction Strategy Transformation. Sustainability 2018, 10, 2934. doi: 10.3390/su10082934.

16. Marx B, Stoker T, and Suri T. The Economics of Slum in the Developing World. Journal of Economic Perspectives, Volume 27, Number 4, Fall 2013, p.187-210. doi: 10.1257/jep.27.4.187.

17. Supriyanto B. Role of Government in Jakarta Organize Slum Area. Scientific Research Journal (SCJR), Volume II, Issue V, May 2014. 
18. Supriatna A and Molen VDP. Land Readjustment for Upgrading Indonesia Kampung: A Proposal. South East Asia Research, 2014, 22, 3, pp 379-397. doi: $10.5367 /$ sear.2014.0218.

19. Ismail F, Jabar LI, Janipha IAN, and Razali R. Measuring the Quality of Life in Low Cost Residential Environment. Procedia-Social and Behavioral Sciences, 168 (2015) 270279. doi: 10.1016/j.sbspro.2014.10.232.

20. Woodhead M. Changing Perspectives on Early Childhood: Theory, Research and Policy. (Cited 2018 October 21). Available from:

http: / / unesdoc.unesco.org/images/0014/0 01474/147499e.pdf

21. Nousi D, Christou, A. Factors Affecting the Quality of Life in Children with Congenital Heart Disease. Health Science Journal, Volume 4, Issue 2 (2010), pp. 94-100.

22. Villalonga-Olives $E$, von Steinbuchel $N$, Witte C, Kasten E, Kawachi I, and KieseHimmel, C. Health Related Quality of Life of Immigrant Children: Towards A New Pattern in Germany? BMC Public Health, 14, 790. doi: 10.1186/1471-2458-14-790.

23. Sommer R, Daubmann A, Quitmann J, Ravens-Sieberer $U$, and Bullinger $M$. Understanding the Impact of Statural Height on Health-related Quality of Life in German Adolescents: A Population-based Analysis. European Journal of Pediatrics (2014) . doi: 10.1007/s00431-014-2480-6.

24. Sieberer RU, and Bullinger M. KINDLR: Questionnaire for Measuring HealthRelated Quality of Life in Children and Adolescents. (cited 2018 October 17). Available from: https://www.kindls.org/english/manual/

25. Han ST, Krone N, et.al. Quality of Life in Adults with Congenital Adrenal Hyperplasia Relates to Glucocorticoid Treatment, Adiposity and Insulin Resistance: United Kingdom Congenital Adrenal Hyperplasia Adult Study Executive (CaHASE). European Journal of Endocrinology (2013) 168887 893. doi: 10.1530/EJE-13-0128.

26. Paavola and Evelin L. The Importance of Emotional Intelligence in Early Children. (cited 2018 November 3). Available from: https: / /www.theseus.fi/bitstream/handle /10024/131619/BA\%20Thesis\%20of\%20Lilla $\% 20$ Paavola.pdf?sequence $=1$
27. Brackett $\mathrm{AM}$ and Rivers ES. Transforming Students' Lives with Social and Emotional Learning: To Appear in the Handbook of Emotions in Education. (cited 2018 November 3). Available from: http: / /ei.yale.edu/wpcontent/uploads/2013/09/TransformingStudents\%E2\%80\%99-Lives-with-Social-andEmotional-Learning.pdf

28. Toscano VE and Amestoy AV. The Relevance of Social Interactions on Housing Satisfaction. Social Indicator Research, April 2007. doi: 10.1007/s11205-007-91075.

29. Zainal RN, Kaur G, Ahmad AN, and Khalili MJ. Housing Condition and Quality of Life of The Urban Poor in Malaysia. Procedia-Social and Behavioral Sciences, Volume 50, 2012, Pp. 827-838.

30. Lee E and Park KM. Housing Satisfaction and Quality of Life Among Temporary Residents in The United Kingdom. Housing and Society, Volume 37, 2010, Issue 1. doi: $10.1080 / 08882746.2010 .11430580$.

31. Swords L, Merriman B, and O'Donnel M. Family Wellbeing on A Limited Income: $A$ Study of Family Living at Risk of Poverty in Ireland. (Cited 2018 November 3). Available from:

http: / /www.drugs.ie/resourcesfiles/Resea rchDocs/Ireland/2013/Family_Wellbeing.p df

32. Reynolds AS, Fernald CHL, Deardorff J, and Behrman RJ. Family Structure and Child Development in Chile: A Longitudinal Analysis of Household Transitions Involving Fathers and Grandparents. Demographic Research, Volume 38, Article 58, p. 17771814, $2018 . \quad$ doi: 10.4054/DemRes.2018.38.58.

33. Kanjilal B, Mazumdar GP, Mukherjee M, and Rahman HM. Nutritional Status of Children in India: Household Socio-Economic Condition as The Contextual Determinant. International Journal for Equity in Health, 2010, 9:19. doi: 10.1186/1475-9276-9-19.

34. Best C, Neufingerl N, van Geel L, van den Briel T, and Osendarp S. The Nutritional Status of School-Aged Children: Why Should We Care? Food and Nutrition Bulletin, 2010 Sep;31(3):400-17. $10.1177 / 156482651003100303$. 